\title{
Impact of Sharia Tourism Development in Pringsewu Regency Lampung
}

\author{
Basrowi ${ }^{1}$, Fauzi $^{2}$, Pertiwi Utami ${ }^{3}$ \\ 1Departement of Islamic Economics, Sekolah Tinggi Ekonomi dan Bisnis Islam Lampung, J1. \\ Jenderal A. Yani No. 67 Gedong Tataan Kabupaten Pesawaran, Lampung 35371, Indonesia \\ ${ }^{2}$ Sekolah Tinggi Manajemen Informatika dan Komputer Lampung, Pringsewu Sel. Kec. \\ Pringsewu Kabupaten Pringsewu Lampung 35373, Indonesia \\ ${ }^{3}$ Masters in Islamic Economics, Universitas Islam Negeri Raden Intan Lampung, Jl. Letnan \\ Kolonel H Jl. Endro Suratmin Sukarame Kec. Sukarame Kota Bandar Lampung 35131, \\ Indonesia \\ e-mail: ${ }^{1}$ basrowi2018@gmail.com ${ }^{2}$ fauzistmik@yahoo.co.id ${ }^{3} \underline{\text { utamipertiwi89@gmail.com }}$
}

\begin{abstract}
The purpose of this study was to describe the opportunities for sharia tourism in Pringsewu Regency by referring to the Law and Fatwa of the National Sharia Council. The research method used is empirical legal research which aims to support the development of legal science, especially sharia law related to halal tourism. Data is collected through documented observation. Examination of the validity of the data by using data source triangulation techniques is done by comparing the results of observational data with the results of related documents, and data analysis through data reduction, data presentation and conclusion drawing. Based on the results of the study concluded, 1) sharia tourism is very possible to be developed in Lampung Province, because formal juridical is not at all contradictory and Law No.33 of 2013 concerning Guaranteed Halal Products; 2) also does not contradict the Fatwa of the National Sharia Council-Indonesian Ulema Council No.108 / DSNMUI / X / 2016 towards the development of sharia tourism.
\end{abstract}

Keywords: sharia tourism, pringsewu, fatwa of the national sharia council

Abstrak: Tujuan penelitian ini adalah untuk mendeskripsikan peluang pariwisata syariah di Kabupaten Pringsewu dengan merujuk pada Undang-Undang dan Fatwa Dewan Syariah Nasional. Metode penelitian yang digunakan adalah penelitian hukum empiris yang memiliki tujuan untuk mendukung perkembangan ilmu hukum terutama hukum syariah yang berhubungan dengan wisata halal. Data dikumpulkan melalui observasi dandokumentasi.Pemeriksaan keabsahan data dengan menggunakan teknik triangulasi sumber data yang dilakukan dengan membandingkan hasil data pengamatan dengan data hasil dokumen yang terkait,dan analisis data melalui reduksi data, penyajian data dan penarikan kesimpulan.Berdasarkan hasil penelitian dapat disimpulkan, 1) wisata syariah sangat memungkinkan dikembangkan di Provinsi lampung, karena secara yuridis formal sama sekali tidak bertentang dan Undang-undang No.33 Tahun 2013 Tentang Jaminan Produk Halal; 2) juga tidak bertentang dengan Fatwa Dewan Syariah Nasional-Majelis Ulama Indonesia No.108/DSN-MUI/X/2016 terhadap pengembangan pariwisata syariah.

Kata kunci: Pariwisata Syariah, Pringsewu, Fatwa Dewan Syariah Nasional

\section{Introduction}

Pringsewu Regency economic growth from year to year continues to experience a fairly good development. In 2016 the Gross Regional Domestic Product (PDRB) at a constant price was
$5.80 \%$. Then in 2017 it increased to $6.95 \%$, and in 2018 it will again increase to $7.10 \%$. While at the end of 2018 , economic growth is predicted to increase again, given the economic structure of Pringsewu Regency which 
92 IQTISHODUNA: Jurnal Ekonomi Islam

Volume 9 Issue 1, April 2020

is dominated by agriculture, forestry and fisheries sectors gives the largest contribution to the growth of Pringsewu's PDRB 1

Lampung Province is known as a region with potential and tourist destinations, now a magnet for tourists. Of the approximately 15 million inhabitants of Jakarta, two million of its citizens travel to a number of attractions in Java and Sumatra including Lampung. If one person carries Rp1 million. This means around Rp. 200 billion spent in Lampung. APBD Lampung 2019 around Rp. 7 trillion more 2 .

Table 1.1 The number of Indonesian and foreign tourists visiting the Province of Lampung in 2012 to 2017

\begin{tabular}{l|l|l|l}
\hline Year & $\begin{array}{l}\text { Archipelago } \\
\text { Tourists }\end{array}$ & $\begin{array}{l}\text { Foreign } \\
\text { Tourists }\end{array}$ & Total \\
\hline 2012 & 2.581 .165 & 58.205 & 2.639 .370 \\
\hline 2013 & 3.392 .125 & 75.590 & 3.467 .715 \\
\hline 2014 & 4.327 .188 & 95.528 & 4.422 .716 \\
\hline 2015 & 5.370 .803 & 114.907 & 5.485 .710 \\
\hline 2016 & 7.381 .774 & 155.053 & 7.536 .827 \\
\hline 2017 & $11,395,827$ & 245.372 & $11,641,199$ \\
\hline
\end{tabular}

Source: Lampung Tourism Office in numbers, 2017.

Seen from the table above, from 2013 to 2017 the number of tourist arrivals in Lampung Province continued to increase. Where, the number of tourists visiting Lampung Province at 6 the number of tourists occurred again in 2015 amounted to $5,645,710$ and 2016 which amounted to $7,536,827$. increased from 2015 to 2016 by $33.49 \%$. The number of Lampung tourists increased again in
2017, recorded 11,641,199 people or an increase of $54.45 \%$ compared to the previous year.

Table 1.2 Total Tourism Sector Revenue in Lampung Province in 2011-2018

\begin{tabular}{l|l|l|l}
\hline Year & $\begin{array}{l}\text { Tourism Sector } \\
\text { Revenue }\end{array}$ & Increase & Percentage \\
\hline 2011 & 27.013 .204 .794 & & \\
\hline 2012 & Rp.32.195.531.029 & Rp.5.182.326.235 & $19 \%$ \\
\hline 2013 & Rp.38.673.529.071 & Rp.6.477.998.042 & $20 \%$ \\
\hline 2014 & Rp.46.605.823.538 & Rp.7.932.294.467 & $21 \%$ \\
\hline 2015 & Rp.51.876.105.748 & Rp.5.270.282.210 & $11 \%$ \\
\hline 2016 & Rp.57.345.654.454 & Rp.5.469.548.706 & $10 \%$ \\
\hline 2017 & Rp.61.345.443.344 & Rp.3.999.788.890 & $7 \%$ \\
\hline 2018 & Rp.67.452.543.543 & Rp.6.107.100.199 & $9 \%$ \\
\hline
\end{tabular}

Source: BPS, Lampung in number, 2011-2018

The table above shows that the increase in revenue from the tourism sector continues to rise in line with the development of tourist destinations, and the many social media that offer attractive tourist destinations.

The tourism segment in Indonesia until 2019 has developed quite well. Based on the records of the Central Statistics Agency (BPS), "The number of foreign tourist arrivals in 2017 has experienced a significant increase reaching $14,039,799$ visits. The number increased by $21.88 \%$ compared to 2016 in the range of 11,519,275 visits. It is estimated that this number will increase to 156 million by 2020, or represent $10 \%$ of the overall tourism segment. "The following is presented the data "Condition of the Indonesian Tourism Industry"3

$$
\text { 3residenri.go.id, 'Capaian Sektor }
$$
Pariwisata 3 Tahun Jokowi - Jk', (2018). 
Development in Pringsewu Regency Lampung

Table 1.3 Conditions of the Indonesian Tourism Industry

\begin{tabular}{|c|c|c|c|c|}
\hline & 2016 & 2017 & 2018 & 2019 \\
\hline $\begin{array}{l}\text { Contribute to } \\
\text { PDB }(\%)\end{array}$ & 11 & 13 & 14 & 15 \\
\hline $\begin{array}{l}\text { State Foreign } \\
\text { Exchange } \\
\text { Revenue } \\
\text { trillion) }\end{array}$ & 172.8 & 182.0 & 223.0 & 275.0 \\
\hline $\begin{array}{l}\text { Labor } \\
\text { Absorption } \\
\text { (million people) } \\
\end{array}$ & 11.7 & 12.4 & 12.7 & 13.0 \\
\hline $\begin{array}{l}\text { Competitiveness } \\
\text { Index (WEF) }\end{array}$ & n.a. & 40 & n.a. & 30 \\
\hline $\begin{array}{l}\text { Overseas } \\
\text { Tourism Visits } \\
\text { (Million) }\end{array}$ & 12 & 15 & 17 & 20 \\
\hline $\begin{array}{l}\text { Archipelago } \\
\text { Tourism Travel } \\
\text { (million) }\end{array}$ & 260 & 265 & 270 & 275 \\
\hline
\end{tabular}

He condition of the Indonesian tourism industry creates a strategic opportunity for the development of Sharia-based Tourism with the characteristics of 'halal tourism' which is a promising tourism concept. The results of the Global Muslim Travel Index (GMTI) study noted that Indonesia ranked first as a popular halal tourist destination in the world with a score of 78 and surpassed 130 other tourist destinations around the world. Meanwhile, Bazazo et al, noted that, "There is a significant relationship between sharia-based tourism services and satisfaction thereby increasing tourist loyalty"5. Not without reason, "The image of tourism is a strong magnet to attract

${ }^{4}$ residenri.go.id. ibid

5Ibrahim Bazazo and others, 'The Impact of Islamic Attributes of Destination on Destination Loyalty via the Mediating Effect of Tourist Satisfaction', International Journal of Business Administration, 8.4 (2017), 65, https://doi.org/10.5430/ijba.v8n4p65. foreign tourists."6. As a country with a majority Muslim population, the substance of Islamic values should be the host of their own country. The urgency of the application of the concept of sharia in economic activities such as the empowerment of human and natural resources is a necessity in the midst of industrial progress and global competition? However, what happens in the middle of the community is that the understanding of the word "sharia" tends to lead to certain religious contexts that have the potential to cause conflict ${ }^{8}$.

Much deeper, the negative effects that often arise are population polarization, disruption to family household life, and the development of consumptive attitudes ${ }^{9}$, and "hedonic behavior that is not in accordance with Islamic teachings"10.

${ }^{6}$ Ana Mano and Rui Augusto da Costa, 'A Conceptual Model of the Antecedents and Consequences of Tourist Destination Image', Procedia Economics and Finance, 23.October 2014 (2015), 15-22 https://doi.org/10.1016/s2212-

5671(15)00466-9.

${ }^{7}$ Muhammad Djakfar, Pariwisata Halal Perspektif Multidimensi (UIN-Maliki Press, 2017), http://www.uinmalikipress.com/.

${ }^{8}$ Dewi Sumiati, Intercultural Communication Based on Local Wisdom That Made the People of Bali Reject Sharia Tourism, Asian Journal of Media and Communication (AJMC), 1.2 (2017), 137-46 http://jurnal.uii.ac.id/AJMC/article/view/ $\underline{9437}$.

${ }^{9}$ Nyoman Urbanus and Febianti, 'Analisis Dampak Perkembangan Pariwisata Terhadap Perilaku Konsumtif Masyarakat Wilayah Bali Selatan', Jurnal Kepariwisataan Dan Hospitalitas, 1.No.2 (2017), 118-33.

10Beben Bahren Lucky Radi Rinandiyana, Deasy Lestary Kusnandar, 'LITERASI ICT DAN PERILAKU 
94 IQTISHODUNA: Jurnal Ekonomi Islam Volume 9 Issue 1, April 2020

Therefore, the role of government regulation is needed ${ }^{11}$ and the National Sharia Board ${ }^{12}$ to provide assistance and supervision of the tourism sector. The government should show optimism about the possibility of future economic welfare recovery by developing Islamic tourism ${ }^{13}$.

According to the GMTI 2018 study, "Some important aspects that support the growth of Muslim tourists are an increase in the Muslim population, the development of the middle class, the number of young people, ease of accessing tourist information, mushrooming Muslim-friendly facilities, and tourism in Ramadan"14. In addition, "The role of human resources, media, research and development, events, state capacity, public and government support, marketing strategies, and

HEDONIST DALAM MEMILIH TEMPAT WISATA DI KALANGAN KELAS MENENGAH SEBAGAI PENGARUH GAYA HIDUP', 2018, 1-13.

11Laurensius Arliman, 'Role Investment in Development Policy of Tourism Economics in West Sumatera Province', 20.2 (2019), 273-94.

${ }^{12}$ Eka Dewi Satriana and Hayyun

Durrotul Faridah, 'Wisata Halal: Perkembangan, Peluang, Dan Tantangan', Journal of Halal Product and Research Vol. 01 No.01, November 2018, 01.01 (2018), 32-43.

${ }^{13}$ Adeline Cristina, 'TOURISM

DEVELOPMENT IN RODNA

MOUNTAINS NATIONAL PARK: THE PUBLIC ADMINISTRATION , A KEY STAKEHOLDER', 2017.

${ }^{14}$ Mastercard \& Crescentrating, 'Mastercard-Crescentrating GMTI 2018 Global Muslim Travel Index 2018', 2018 https://www.halalmedia.jp/wpcontent/uploads/2018/04/GMITI-Report2018.pdf. infrastructure are vital requirements. Furthermore, from the perception of experts, public and government support, marketing strategies, and human capital"15.

The real opportunities of sharia-based tourism destinations and the potential of tourism objects owned are not wasted by the Pringsewu district government. Therefore, local governments need to start mimicking the concept of tourism which is based on the sharia concept. This can be done by the local government through empowering the potential of the Pringsewu regency area effectively and efficiently. As research by Adinugraha, Sartika and Kadarningsih, who found that, "One of the potential directions for the development of the tourism sector is the concept of a halal tourism village"16. Can also go through, "Islamic tourism market"17, halal product 18 and sharia hotels ${ }^{19}$.

${ }^{15}$ Mahdi Borzooei and Maryam Asgari, 'Establishing a Global Halal Hub: InDepth Interviews', International Journal of Academic Research in Business and Social Sciences, $\quad 3.10 \quad$ (2013), 169-81 https://doi.org/10.6007/ijarbss/v3i10/288.

16Hendri Hermawan Adinugraha, Mila Sartika, and Ana Kadarningsih, 'Desa Wisata Halal: Konsep Dan Implementasinya Di Indonesia', Human Falah, 5.Nomor 1 (2018), Januari-Juni.

${ }^{17}$ Ade Ela Pratiwi, 'ANALISIS PASAR WISATA SYARIAH DI KOTA YOGYAKARTA', IOSR Journal of Economics and Finance, $3.1 \quad$ (2016), 56 https://doi.org/https://doi.org/10.3929/et $\underline{\text { hz-b-000238666. }}$.

${ }^{18}$ Arshia Mukhtar and Muhammad Mohsin Butt, 'Intention to Choose Halal Products: The Role of Religiosity', Journal of 
Development in Pringsewu Regency Lampung

All of the above conditions will make it possible to increase employment and economic growth 20 , improve tourism performance ${ }^{21}$, improve the competitiveness of tourist destinations with multidimensional concepts that include economic, social, cultural, political, technological, and environmental excellence ${ }^{22}$, and mapping the potential of attractions in order to maximize the potential of existing tourism ${ }^{23}$.

This research would like to answer, how is Pringsewu regional government's strategy in realizing sharia tourism through halal local food production, sharia hotels or home stays, sharia travel agents, sharia tourism villages, sharia

Islamic Marketing, 3.2 (2012), $108-20$ https://doi.org/10.1108/1759083121123251 g.

${ }^{19}$ Fahruddin Ali Sabri, ‘Perkembangan Hotel Syari' ah Di Indonesia; Mengonsep Pariwisata Islami', Karsa, XVIII.2 (2010).

20Satriana and Faridah. Wisata halal: perkembangan, peluang, dan tantangan, 33 Journal of Halal Product and Research (JHPR) Vol. 01 No.02, Mei-November (2018)

${ }^{21}$ Victoria Lelu Sabon and others, 'Strategi Peningkatan Kinerja Sektor Pariwisata Indonesia Pada ASEAN Economic Community', Esensi: Jurnal Bisnis Dan Manajemen, $8.2 \quad$ (2018), $\quad 163-76$ https://doi.org/10.15408/ess.v8i2.5928.

22Tatjana Dimoska and Boris Trimcev, 'Competitiveness Strategies for Supporting Economic Development of the Touristic Destination', Procedia - Social and Behavioral Sciences, 44.local 123 (2012), 27988

https://doi.org/10.1016/i.sbspro.2012.05.03 $\underline{1}$.

${ }^{23}$ Yeni Elda Niasari, 'PEMETAAN POTENSI OBJEK WISATA ALAM DI WILAYAH KABUPATEN PRINGSEWU TAHUN 2017', 2017 (2017). tourism markets in accordance with Law No. 33 of 2014 and according to the MUI National Sharia Council Fatwa.

The originality of this research lies in the legal basis that can be used in realizing sharia tourism at the district / city level, as well as the implications for the realization of other sharia districts / cities in Indonesia.

\section{Theoritical}

In the context of Islamic Economics, tourism is a human effort to obtain a halal fortune, obtain useful knowledge, safar or take a religious journey that has the main goal to obtain the blessing of Allah $\mathrm{SWT}^{24}$. Tourism is valued as an individual's belief and as a source of socio-economic development ${ }^{25}$. Sharia-based tourism is a concept of developing Islamic economics based on the Qur'an and Sunnah 26.

$\mathrm{n}$ understanding Islam, tourism should be linked to knowledge and knowledge. At the beginning of Islam, there has been a very grand journey with the aim of seeking knowledge and spreading it. Until Al-Khatib Al-Bagdady wrote the famous book "Ar-Rihlah Fi Thalabil

${ }^{24}$ Rahmi Syahriza, 'Pariwisata Berbasis Syariah ( Telaah Makna Kata Sara Dan Derivasinya Dalam Al- Qur ' an )', Human Falah, 2014, 135-45.

25Jafar Jafari and Noel Scott, 'Muslim World and Its Tourisms', Annals of Tourism Research, $44.1 \quad$ (2014), 1-19 https://doi.org/10.1016/j.annals.2013.08.01 $\underline{1 .}$

26Syahriza. Pariwisata Berbasis Syariah (Telaah Makna Kata Sara dan Derivasinya dalam al-Qur'an),Jurnal Human Falah vol.1 no.2 juli (2014). 
Hadith", he collected stories of people who traveled only to gain knowledge and search for just one hadith. Among them is what is said by some tabiin, the Word of Allah SWT.



The meaning:

They are people who repent, worship, who praise, who visit, who bow, who prostrate, who ordered to do Ma'ruf and prevent Munkar and who keep the laws of God. and cheer up those believers. (Q.S. Al Taubah: 112)

Ikrimah said "As Saa'ihuna" they are seekers of knowledge. Narrated by Ibn Abi Hatim in his interpretation, 7/429. Please see Fathul Qadir, $2 / 408$. Although the interpretation is correct according to the majority of salaf scholars that what is meant by "As-Saaihin" are those who fast. Tours with the aim of taking lessons and warnings. In the Qur'an there are commands to walk the earth in several places surah al-An'am: 11 and al-Naml: 69. Safar or tours to contemplate the beauty of God's creation, ala, enjoy the beauty of the great nature as a booster human soul to strengthen faith in the oneness of Allah and motivate the fulfillment of the obligation of life as mentioned by Allah in the Qur'an surah Ankabut: 20.
When Allah calls "walk on the earth", it means God reminds us of this nature, so there is a natural tour. Many things can be used as tourist attractions, that's why God created this nature with its diverse characteristics. So, in Islamic law has been explained clearly about the permissibility of tourism to various places around the world with specific aims and objectives.

According to UU No. 9 of 1990, about tourism is everything related to tourism, including tourism object entrepreneurs and tourist attraction as well as businesses related to the field. ${ }^{27}$.

According to Hutabarat (1992), the role of tourism is first, the role of the economy as a source of foreign exchange for the country. secondly, the social role as job creation and business opportunities. Third, the role of culture as a forum to promote and preserve culture, tourism, arts, and others ${ }^{28}$.

\section{Methodology}

This type of research used by researchers is empirical legal research that has the aim to support the development of legal science, especially sharia law related to halal tourism. This research is a descriptive research. The focus of the study was the implementation of the

27Presiden Republik Indonesia,
'Undang-Undang No.9 Tahun 1990 Tentang
Kepariwisataan', 4 1990, $1-9$
https://doi.org/10.1006/bulm.2002.0313.
28Faisal Zumli, 'Peranan Sektor
Pariwisata Terhadap Pendapatan Asli
Daerah (PAD) Di Provinsi Lampung',
Tesis:Universitas Islam Negeri Yogyakarta,
2018,1-19.


Government of Indonesia Law No.33 of 2013 concerning the Guarantee of Halal Products and Fatwa of the National Sharia Council-Indonesian Ulema Council No.108 / DSN-MUI / X / $2016^{29}$ towards the development of sharia tourism. The location of this research is Pringsewu Regency, Lampung Province. Data collected through observation and documentation. Checking the validity of the data by using data source triangulation techniques is done by comparing the results of observational data with data related to the results of documents, and data analysis through data reduction, data presentation and drawing conclusions.

\section{Results And Discussion}

4.1 Organization of Tourism Based on Sharia Principles

Implementation of Tourism Based on Sharia Principles based on the National Sharia Council FatwaMUI Fatwa NO: 108 / DSN-MUI (X) 2016. In the General Provisions in this fatwa the first intended meaning of tourism: 1) Tourism is a travel activity carried out by someone or a group of people by visiting certain places for recreational purposes, personal development, or studying the uniqueness of tourist attractions visited in the interim period, 2) Sharia Tourism is tourism in accordance with sharia principles, 3 ) Tourism is a variety of tourist activities and is supported by

${ }^{29}$ Fatwa Dewan Syariah Nasional. Fatwa Dewan Syariah Nasional-Majelis Ulama Indonesia: Pedoman Penyelenggaraan Pariwisata Berdasarkan Prinsip Syariah. various facilities and services provided by the community, business people, government and regional governments, 4) Sharia Tourism is tourism that complies with sharia principles, 5) Sharia Tourism Destinations are geographical areas within one or more administrative regions within which there are tourist attractions, religious and public facilities, tourism facilities ta, accessibility, and community that are interrelated and complement the realization of tourism in accordance with sharia principles, and 6) Tourists are people who travel.

Then furthermore about all sharia tourism activities namely: 1) Sharia Travel Bureau (BPWS) is a commercial business activity that regulates, and provides services for a person or group of people, to travel with the main purpose of traveling in accordance with sharia principles, 2 ) A Tour Guide is a person who guides in sharia tourism, 3) a Tourism Entrepreneur is a person or group of people who carry out tourism business activities, 4) Sharia Hotel Business is providing accommodation in the form of rooms in a building that can be equipped with dining services and drinking, entertainment activities and / or other facilities on a daily basis with the aim of obtaining profits that are run according to sharia principles, 5) Sharia Business Business Criteria is the formulation of qualifications and / or classifications covering aspects of products, services, and management, and 6) Therapists are parties who perform spa, sauna and or massage. 
The contracts in sharia tourism activities are: 1) The ijarah agreement is a contract for transferring the use rights (benefits) of an item or service within a certain time with payment or wages, 2) A wakalah bil ujrah agreement is a contract of authorization accompanied by compensation from the hotel sharia to BPWS for marketing, and 3) A $j u$ 'alah contract is a promise or commitment (iltizam) for a company to provide certain rewards ('iwadh / $\left.j u^{\prime} l\right)$ to workers ('amil) for achieving results (achievement / natijah) determined from a job (ju'alah contract object).

The legal provisions for organizing tourism based on sharia principles may be carried out on the condition that they follow the provisions contained in this fatwa. Organizing tourism must avoid polytheism, immorality, disobedience, tabdzir / israf, and munkar, and create benefits and benefits both materially and spiritually. Whereas the provisions of sharia hotels where hotel managers and employees are required to wear clothing according to Islamic sharia and sharia hotels are required to have service guidelines to guarantee shariacompliant services. and female therapists are only for female consumers.

Similarly, the provisions of Islamic travel agencies have travel guides that prevent shirk, khurafat, immorality, adultery, pornography, porno-action, alcohol, drugs, and gambling. On the provisions of Islamic tourism guides, human resources, Islamic tourism guides

must understand and implement the values sharia values in their duties, have good character, communicative, friendly, honest, and responsible. In this provision, sharia tour guide human resources are required to have work competencies according to professional standards as evidenced by a competency certificate.

\subsection{Halal Cuisine in Supporting} Sharia Tourism

UU 33 of 2013 concerning Halal Product Certification consists of 68 articles. The law explains that products that enter, circulate and trade in the Territory of Indonesia must be halal-certified. Therefore the Government is responsible for organizing the Halal Product Guarantee (JPH). To carry out the implementation of JPH according to this Law, a Halal Product Guarantee Agency (BPJPH) is established and is responsible for and responsible to the Minister of Religion. BPJPH's organizational structure is regulated in Presidential Regulation Article 5 Paragraph (5) of UU No. 33 of 2014.

In organizing Halal Product Guarantees, BPJPH has the authority to, among others: 1) formulate and set JPH policies, 2) set JPH norms, standards, procedures and criteria, 3) Issue and revoke Halal Certificates on foreign products, 4) and register Halal Certificates on overseas Products. In carrying out the authority referred to, $\mathrm{BPJPH}$ cooperates with relevant ministries and / or institutions, the Halal Examining Agency (LPH), and the Indonesian Ulema Council (MUI), reads Article 7 of this Law. 
As for the mechanism, this Act confirms that the application for Halal Certificate is submitted by Business Actors in writing to BPJPH. Furthermore, BPJPH establishes LPH to conduct inspection and / or testing of Product halalness. Halal product inspection and / or halal testing is carried out by the Halal Auditor at the business location during the production process. In the event that the product inspection is referred to as having a halal substance, doubtful testing can be carried out in a laboratory, "reads Article 31 Paragraph (3) of UU Number 33 Year 2014.

Furthermore, LPH submits the results of inspection and / or product halal testing to $\mathrm{BPJPH}$ to be submitted to the Indonesian Ulema Council (MUI) in order to obtain a product halal determination.

MUI will hold a Halal Fatwa Session to determine the halalness of the Product no later than 30 (thirty) working days from the receipt of the results of the inspection and / or product testing from the BPJPH. The decision to determine Halal Products will be submitted by MUI to BPJPH to be the basis for the issuance of Halal Certificates. In the event that the Halal Fatwa Session declares that the Product is not halal, BPJPH returns the application for Halal Certificate to the Business Actor accompanied by the reason, reads Article 34 Paragraph (2) of this UU.

While those declared as halal by the MUI Halal Fatwa Session will be the basis for BPJPH to issue Halal Certificates no later than 7 (seven) working days from the receipt of the Product halal decision received from the MUI. According to this Act, Business Actors who have obtained Halal Certificates are required to attach a Halal Label to the product packaging and certain parts of the Product; and / or certain places on the Product. The inclusion of the Halal Label must be easily seen and read and not easily deleted, removed and tampered with, Article 39 of Law Number 33 Year 2014 reads. Halal Certificate is valid for 4 four years since it was issued by BPJPH, and must be extended by Business Actors by submitting an Halal Certificate renewal no later than 3 (three) months prior to the validity period of the Halal Certificate.

Halal Certificates which have been established by the MUI before this Law is valid are stated to remain in force until the term of the Halal Certificate is valid. And before $\mathrm{BPJPH}$ was formed, the submission of application or extension of Halal Certificate was carried out in accordance with the procedures in force before this Law was enacted. The Act also emphasized that MUI continued to carry out its duties in the field of Halal Certification until $\mathrm{BPJPH}$ was formed. BPJPH must be established no later than 3 (three) years from the enactment of this Act, reads Article 64 of Law No. 33/2014.

The regulations for the implementation of this Act must be set no later than 2 (two) years from the enactment of this Act. "This law came into force on the date of promulgation," said Article 68 of the Law promulgated by the Minister of Law and Human Rights Amir Syamsudin on 17 October 2014. 
4.4 The Role of Local Government in the Development of Sharia Tourism

Based on the Pringsewu

District Regulations No. 02 of 2011, concerning the Organizational Structure and Work Procedure (STOK) of the Pringsewu District Offices as amended by the Pringsewu District Regulations No. 07 of 2012, the Pringsewu District Youth and Sports Service is the Regional household organizer in the field of Youth and Sports. Referring to the Pringsewu Regency Mid-term Regional Development Plan (RPJMD) in 2011-2016, the Department of Youth and Sports has also drawn up a Regional Work Unit Strategy Plan (SKKPD Strategy Plan), adjusting to Regional Regulation No. 16 of 2016 concerning the formation and composition of regional apparatus Pringsewu Regency. Based on the regional regulation starting in January 2017, the Dispora SKPD Nomenclature of Pringsewu Regency was changed to the Office of Youth and Tourism Sports (DISPORPAR).

The Vision of the Sports and Tourism Youth Service (DISPORPAR) is "The Realization of the Pringsewu District Community that is Advanced, Independent, Professional and Competitive through the Development of Youth and Sports and Tourism." The detailed purpose of the vision is: 1) going forward means having a clear direction going forward in accordance with a definite goal, 2) being independent means having the ability of oneself to develop in overcoming himself, 3) professional means having competence in the field occupied by mastery science and technology, and 4) competitiveness means better, stronger and tougher than the environment.

The mission of the Sports and Tourism Youth Service (DISPORPAR), namely: 1) exploring the potential of human resources in the field of Youth, sports and Tourism, 2) Empowering Youth Activities and Independent Organizations, 3) developing Superior Sports Achievement, 4) empowering the community economy and an increase in Regional Original Revenue (PAD) from the tourism sector, 5) developing the Potential of Tourism Attraction (DTW) and tourism partnerships, and 6) encouraging the private sector to participate in Youth Sports and Tourism Development.

The scope of its activities are: 1 ) expansion and improvement of sports and tourism youth access and potential, 2) strengthening governance, imaging, public and accountability, development and utilization of sports and tourism youth facilities and infrastructure, with priority scale, and 3) improvement the competence and professionalism of youth and sports practitioners, through the development of youth entrepreneurship, rehabilitation of sports facilities and infrastructure, improvement of sports achievements, and improvement and development of tourism

In accordance with the SKPD work plan document of the Youth and Tourism Department for the 2017 Fiscal Year, it is explained in the technical field of tourism: 1) The Tourism Marketing Development Program which includes the development of a tourism promotion cooperation network, and the implementation of domestic tourism promotion within and outside the country; 2) tourism destination development program which includes development of leading tourism objects and Improvement of tourism facilities and infrastructure development, 3) 
Development in Pringsewu Regency Lampung

partnership development program, namely human resource development in the field of culture and tourism in cooperation with other institutions.

Location of tourism objects in Pringsewu Regency are scattered in several districts. Some of them are owned by the Lampung Provincial Government BSDA (Talng Indah Bukit Pangonan). However, based on the results of facilitation and assistance in 13 attractions it turns out that the condition is currently growing independently and is not well coordinated. Specifically for the leading tourist attraction Talang Bukit Pangonan apparently has not been able to be maximally empowered. Even until 2018 the target of PAD achievement is very low. Target PAD Talang Indah Pangonan tourist attraction data. The following researchers present the target data for the realization of PAD and tourist attractions in Prinsewu Regency, as follows:

Table 4.1 PAD Realization Target of Talang Indah Bukit Pangonan tourism object

\begin{tabular}{|l|l|l|l|}
\hline No & Year & $\begin{array}{l}\text { Number } \\
\text { of } \\
\text { visitors }\end{array}$ & $\begin{array}{l}\text { Contribution } \\
\text { to PAD }\end{array}$ \\
\hline 1 & 2016 & 71.016 & 1.207 .272 .000 \\
\hline 2 & 2017 & 50.876 & 915.768 .000 \\
\hline 3 & $\begin{array}{l}2018 \text { s.d } \\
\text { August }\end{array}$ & 52.567 & 998.773 .000 \\
\hline
\end{tabular}

Source: ${ }^{30}$

\begin{tabular}{lrr}
\hline \multicolumn{2}{c}{${ }^{30}$ Samsir } & \multicolumn{2}{c}{ Kasim, } & \\
PENRATEGI \\
PENGEMBANGAN OBYEK & WISATA \\
UNGGULAN UNTUK MENINGKATKAN \\
EKONOMI MASYARAKAT $\quad$ DI \\
KABUPATEN PRINGSEWU', 2018, 1-35.
\end{tabular}

Table 4.2 Tourist Attraction location in Pringsewu district

\begin{tabular}{l|l|l|l|l|l}
\hline No & $\begin{array}{l}\text { Tourist } \\
\text { Attraction }\end{array}$ & Location & No & $\begin{array}{l}\text { Tourist } \\
\text { Attraction }\end{array}$ & Location \\
\hline 1 & $\begin{array}{l}\text { Air terjun } \\
\text { Selapan }\end{array}$ & Padarsuka & 8 & $\begin{array}{l}\text { Agroforestr } \\
\text { y Telaga } \\
\text { ngundi }\end{array}$ & Sukoharjo \\
\hline 2 & $\begin{array}{l}\text { Agrowisata } \\
\text { Kolam } \\
\text { Pagelaran }\end{array}$ & Pringsewu & 9 & $\begin{array}{l}\text { Embung } \\
\text { Fajar } \\
\text { Agung }\end{array}$ & Pringsewu \\
\hline 3 & $\begin{array}{l}\text { Bukit } \\
\text { Pagana }\end{array}$ & Ka. Pringsewu & 10 & $\begin{array}{l}\text { Putri Giri } \\
\text { Sutra } \\
\text { MandalaTe } \\
\text { gal Sari }\end{array}$ & $\begin{array}{l}\text { Gading } \\
\text { Rejo }\end{array}$ \\
\hline 4 & $\begin{array}{l}\text { Bukit } \\
\text { Blitarejo }\end{array}$ & Kab.Pringsewu & 11 & $\begin{array}{l}\text { Air terjun 7 } \\
\text { tingkat } \\
\text { Girimulyo }\end{array}$ & $\begin{array}{l}\text { Pagelaran } \\
\text { utara }\end{array}$ \\
\hline 5 & Bukit & Kanjarejo & Kab.Pringsewu & 12 & $\begin{array}{l}\text { Talang Air } \\
\text { Pringsewu }\end{array}$ \\
\hline 6 & $\begin{array}{l}\text { Bukit } \\
\text { Tursina }\end{array}$ & Kab.Pringsewu & 13 & $\begin{array}{l}\text { Telaga } \\
\text { Gupit } \\
\text { Tegalsari }\end{array}$ & Gading rejo \\
\hline 7 & $\begin{array}{l}\text { Bukit } \\
\text { Pangonan }\end{array}$ & Kab.Pringsewu & 17 & $\begin{array}{l}\text { Air terjun } \\
\text { Selapan }\end{array}$ & Padarsuka \\
\hline SOurgana
\end{tabular}

Source: 31

In order to develop the concept of sharia economy in Pringsewu District, the Financial Services Authority (OJK) Lampung conducted an assessment of the potential of sharia economy in the regency with a 2018 APBD revenue of one trillion through the development of sharia tourism. To accelerate the sharia economic development program, OJK Lampung is coordinating with the Indonesian Ulema Council (MUI) as the originator of sharia economics with a new paradigm called "The New Flow of Indonesia's Economy". "However, this cultural tourism object has not been fully functioned properly such as with the holding of a cultural festival or other.

In addition, the existing local culture also cannot be touched and moved into a strength and strategic potential. With high economic potential, it is expected to be able to realize the Islamic market that is able to raise the economic level of the society of Bumi Jejama Secancanan.

\footnotetext{
${ }^{31}$ Kasim. ibid
} 
102 IQTISHODUNA: Jurnal Ekonomi Islam

Volume 9 Issue 1, April 2020

As explained above, that one of the characteristics of the development of sharia tourism is halal products. The handling of halal certification has so far been the authority of the Food and Drug Research and Research Institute (LPPOM) MUI, which is a nongovernmental organization of various Islamic elements in Indonesia. After the enactment of Law Number 33 of 2014 concerning Halal Product Guarantee, halal certification becomes the authority of the Halal Product Guarantee Agency (BPJPH) which is a state institution of the Republic of Indonesia.

Based on the results of information gathering and data regarding the development of sharia tourism in Pringsewu district, the following results were obtained. First, to realize sharia tourism requires efforts to change the mindset (mindset) of the community, practitioners and related parties so that the concept of sharia can be realized properly. In addition to halal foods and drinks and according to sharia life style (lifestyle) also must be halal. At the moment Pringsewu already has an Islamic hotel and this confirms that there is no reason not to realize Islamic tourism.

Second, as one of the strategies to realize sharia economy through sharia tourism is to focus on the formation of the Regional Financial Access Acceleration Team (TPAKD) to empower tourism potentials, the establishment of Sharia Microfinance Institutions (LKMS) for the development of sharia tourism businesses and sharia markets. The formation of the TPAKD was a follow-up to the Minister of Home Affairs Radiogram No.T-900/634/ Keuda dated February 19, 2016, which asked the Regional Head, in this case the Governor, the Regent and the Mayor, together with the FSA to form the TPAKD in the provinces, districts, cities. The initiative to establish TPAKD was motivated by the need to increase the acceleration of financial access that could encourage economic growth in the region.

With this step, it is expected to be able to move the community's economy, which in turn will also benefit the community. In principle, the Pringsewu district government strongly supports sharia tourism activities and programs. The local government through the youth service of sports and tourism has set 13 tourist destinations in Pringsewu. But to this day, people do not know for sure, where the direction and plans of the development of existing tourist destinations.

\section{Conclusion}

From the analysis, the researcher concluded that the application of Pringsewu District Tourism in the DSN-MUI Fatwa Review Number: 108 DSN-MUI / 2016 concerning Guidelines for Organizing Tourism Based on Sharia Principles and Law Number 33 Year 2014 Regarding Halal Product Guarantee has not been fully realized. The role of the Indonesian Ulema Council and Government Regulation is needed to support the development of Islamic tourism. With the support of all related parties, it can accelerate the 
Development in Pringsewu Regency Lampung

process of applying empirical law that applies in Pringsewu district and is expected to improve the economy of its people. In the future, the development of sharia tourism must also pay attention to the current development of the digital technology industry. Seeing that the potential of Pringsewu regency's sharia tourism has a pretty good prospect.

\section{REFERENCES}

Adinugraha, Hendri Hermawan, Mila Sartika, and Ana Kadarningsih. Desa Wisata Halal: Konsep Dan Implementasinya Di Indonesia. Human Falah, 5 (2018), JanuariJuni

Arliman, Laurensius. Role Investment in Development Policy of Tourism Economics in West Sumatera Province. 20 (2019), 273-94

Bazazo, Ibrahim, Tariq Elyas, Loay Awawdeh, Myada Faroun, and Sa'ad Qawasmeh. The Impact of Islamic Attributes of Destination on Destination Loyalty via the Mediating Effect of Tourist Satisfaction. International Journal of Business Administration, 8 (2017), 65

https://doi.org/10.5430/ijba.v8n $\underline{4 p 65}$

Borzooei, Mahdi, and Maryam Asgari, Establishing a Global Halal Hub: In-Depth Interviews. International Journal of Academic Research in Business and Social Sciences, 3 (2013), $169-81$ https://doi.org/10.6007/ijarbss/ v3-i10/288

Cristina, Adeline. 2017. Tourism Development In Rodna Mountains National Park: The Public Administration, A Key Stakeholder,
Dimoska, Tatjana, and Borjis Trimcev. Competitiveness Strategies for Supporting Economic Development of the Touristic Destination. Procedia Social and Behavioral Sciences, 44 (2012),

279-88 https://doi.org/10.1016/j.sbspro. 2012.05.031

Djakfar, Muhammad. 2017. Pariwisata Halal Perspektif Multidimensi. Malang: UIN-Maliki Press. http:/ / www.uinmalikipress.com

Fatwa Dewan Syariah Nasional. 2016. Fatwa Dewan Syariah NasionalMajelis Ulama Indonesia: Pedoman Penyelenggaraan Pariwisata Berdasarkan Prinsip Syariah.

Indonesia, Presiden Republik. UndangUndang No. 9 Tahun 1990 Tentang Kepariwisataan. 1990, 19

https://doi.org/10.1006/bulm.20 $\underline{02.0313}$

Jafari, Jafar, and Noel Scott, 'Muslim World and Its Tourisms', Annals of Tourism Research, 44 (2014), 1-19 https://doi.org/10.1016/j.annals. 2013.08.011

Kasim, Samsir. Strategi Pengembangan Obyek Wisata Unggulan untuk Meningkatkan Ekonomi Masyarakat di Kabupaten Pringsewu. 2018, 1-35

Keuangan, Nota. Nota Keuangan (Beserta Rancangan Anggaran Pendapatan dan Belanja Negara). 2019, 3

Lampung, Pemerintah Provinsi. Laporan Kinerja Instansi Pemerintah (LKIP) TAHUN 2017. 2017

Lucky Radi Rinandiyana, Deasy Lestary Kusnandar, Beben Bahren. Literasi ICT dan Perilaku Hedonist dalam Memilih Tempat Wisata di Kalangan Kelas Menengah sebagai Pengaruh Gaya Hidup. 2018, 1-13 
104 IQTISHODUNA: Jurnal Ekonomi Islam

Volume 9 Issue 1, April 2020

Mano, Ana, and Rui Augusto da Costa. A Conceptual Model of the Antecedents and Consequences of Tourist Destination Image. Procedia Economics and Finance, 23 (2015), $15-22$ https:// doi.org/10.1016/s22125671(15)00466-9

Mastercard \& Crescentrating. 2018. Mastercard-Crescentrating GMTI 2018 Global Muslim Travel Index 2018.

https://www.halalmedia.jp/wpcontent/uploads/2018/04/GMIT I-Report-2018.pdf

Mukhtar, Arshia, and Muhammad Mohsin Butt. Intention to Choose Halal Products: The Role of Religiosity. Journal of Islamic Marketing, 3 (2012), 108-20 https://doi.org/10.1108/1759083 1211232519

Niasari, Yeni Elda. 2017. Pemetaan Potensi Objek Wisata Alam di Wilayah Kabupaten Pringsewu Tahun 2017.

Pemerintah Republik Indonesia. Undang - Undang Republik Indonesia No. 33 Tahun 2014 Tentang Jaminan Produk Halal. Kementrian Agama Republik Indonesia, 2014, pp. 1-5 https://doi.org/10.1007/s13398014-0173-7.2

Pratiwi, Ade Ela. Analisis Pasar Wisata Syariah di Kota Yogyakarta, IOSR Journal of Economics and Finance, 3 (2016), 56 https://doi.org/https://doi.org/ $\underline{10.3929 / \text { ethz-b-000238666 }}$

residenri.go.id. 2018. Capaian Sektor Pariwisata 3 Tahun Jokowi - Jk.

Sabon, Victoria Lelu, Mochamad Tommy Putra Perdana, Permata Citra Stella Koropit, and Wajong
Christian David Pierre. Strategi Peningkatan Kinerja Sektor Pariwisata Indonesia Pada ASEAN Economic Community. Esensi: Jurnal Bisnis dan Manajemen, 8 (2018), 163-76 https://doi.org/10.15408/ess.v8i 2.5928

Sabri, Fahruddin Ali. 2010. Perkembangan Hotel Syari'ah di Indonesia; Mengonsep Pariwisata Islami', Karsa, XVIII

Satriana, Eka Dewi, and Hayyun Durrotul Faridah. Wisata Halal: Perkembangan, Peluang, Dan Tantangan. Journal of Halal Product and Research Vol. 01 No.01, November 2018, 01 (2018), 32-43

Sumiati, Dewi. Intercultural Communication Based on Local Wisdom That Made the People of Bali Reject Sharia Tourism. Asian Journal of Media and Communication (AJMC), 1 (2017), 137-46

http://jurnal.uii.ac.id/AJMC/arti cle/view/9437

Syahriza, Rahmi. Pariwisata Berbasis Syariah (Telaah Makna Kata Sara Dan Derivasinya dalam alQur'an). Human Falah, 2014, 13545

Urbanus, Nyoman, and Febianti. Analisis Dampak Perkembangan Pariwisata Terhadap Perilaku Konsumtif Masyarakat Wilayah Bali Selatan. Jurnal Kepariwisataan Dan Hospitalitas, 1 (2017), 118-33

Zumli, Faisal. Peranan Sektor Pariwisata Terhadap Pendapatan Asli Daerah (PAD) di Provinsi Lampung. Tesis: Universitas Islam Negeri Yogyakarta, 2018, 1-19 